American Journal of Economics and Business Administration 2 (3): 240-246, 2010

ISSN 1945-5488

(C) 2010 Science Publications

\title{
Prospects of Waterway Development as a Catalyst to Improve Regional and Community Socio-Economy Level
}

\author{
Sulaiman M. Yassin, Hayrol Azril Mohamed Shaffril, Md. Salleh Hassan, \\ Mohd. Shahwahid Othman, Asnarulkhadi Abu Samah and Bahaman Abu Samah \\ Laboratory of Rural Advancement and Agriculture Extension, \\ Institute for Social Science Studies, University Putra Malaysia, 43400, \\ Serdang, Selangor Darul Ehsan, Malaysia
}

\begin{abstract}
Problem statement: Malaysia has achieved a number of successes in its transportation development. The success of Kuala Lumpur International Airport and Northern and Southern Highway project for example have given the community a lot of benefits in term of social and economic development, but what if an inland waterway system can be developed in Malaysia especially along the Pahang River and Muar River. Can this proposed waterway bring significant impact to local people in term of their social and economic development? This has become the main objective of this study which is to investigate whether the future Pahang Muar Waterway could have significant socioeconomic impact on the local community or not. Approach: This is a qualitative study. Observations, structured and unstructured in-depth interview and literature analysis were used to gain the data needed and the research team had traversed along these rivers (Muar to Bahau and ended in Pekan). For the indepth interviews, a total of seventeen informants among the public and government officers were selected. Data from the in-depth interviews were transcribed verbatim and subsequently analyzed by identifying similarities and consistent themes. A constant comparative method was employed in order to uncover patterns in the data. The data in this study is presented descriptively. Results: From the observation, interviews and literature analysis done, it can be concluded that the Pahang Muar Waterways is believed to develop economic activities, recreational activities, tourism industry, enhance the socio-economic life of local community and provide sustainable mobility. Conclusion/Recommendations: From the results gained, it can be concluded that a majority of the community interviewed believed that Pahang Muar waterways offer a vast opportunity for social and economic development for the local community. It can be noted that specific planning on constructing the inland waterways should be started by the local authorities. It is recommended that specific studies on the feasibility of inland waterways in Malaysia in term of technicality, environmental impact, social development and economic development should be initiated.
\end{abstract}

Key words: Waterways, development, economy activities, recreational activities, tourism, socioeconomy and sustainable mobility

\section{INTRODUCTION}

Malaysia is a well known developing country and through its Vision 2020 is heading to be a developed country. As a developing country, Malaysia has achieved numerous successes in almost every aspect of development. Transportation system is one of it. The introduction of mega projects such as the NorthSouth Highway Project (PLUS) covering a distance of almost $996 \mathrm{~km}$, East Coast Highway covering a distance of $330 \mathrm{~km}$ and the famous duo functions
Smart Tunnel in Sungai Besi, Kuala Lumpur are proven examples. To further prove that Malaysia has achieved a number of significant successes in transportation systems is the construction of Kuala Lumpur International Airport (KLIA), currently listed as one of the top ten airports in the world, the emergence of low cost carrier company, Air-Asia and not to forget the commuter and LRT transportation systems. But, how about the waterway transportation? The waterway network is indeed an important catalyst to boost the economic activity among the local community.

Corresponding Author: Sulaiman M. Yassin, Laboratory of Rural Advancement and Agriculture Extension, Institute for Social Science Studies, University Putra Malaysia, 43400, Serdang, Selangor Darul Ehsan, Malaysia 


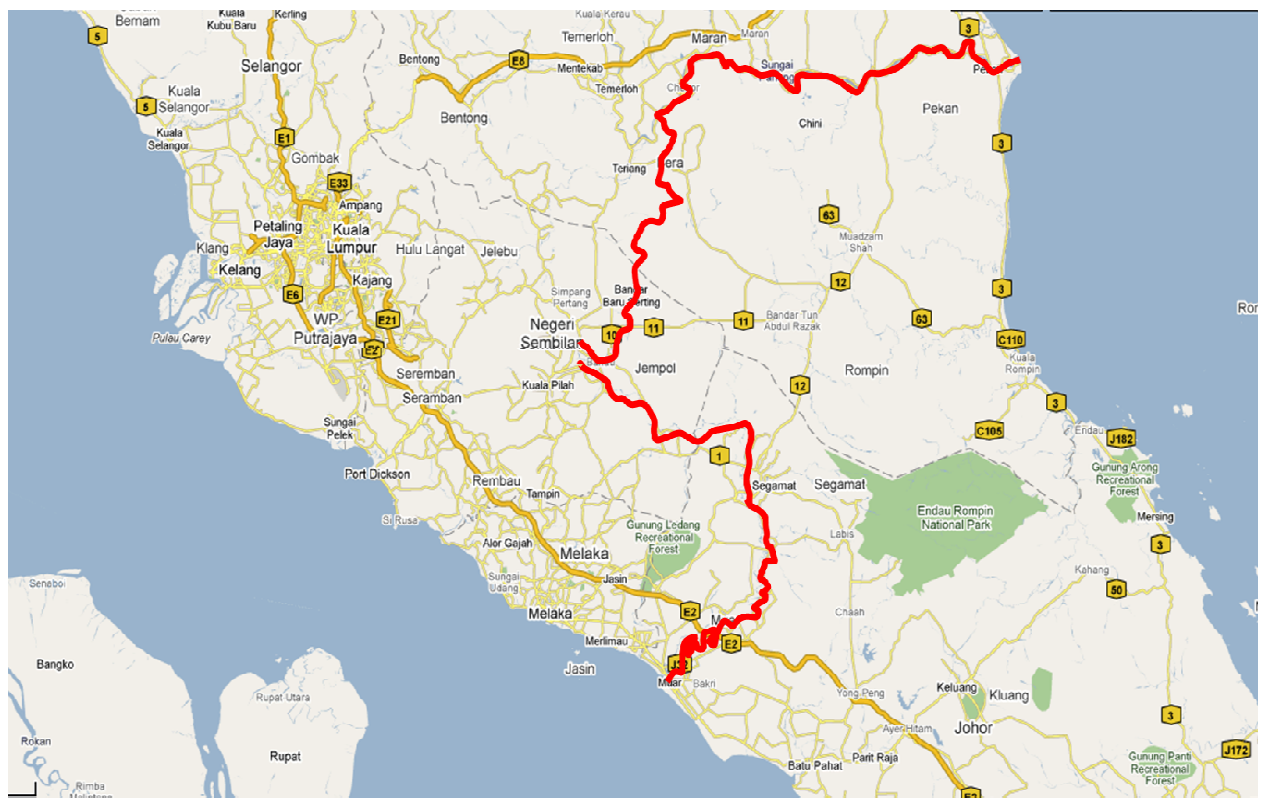

Fig. 1: The flows of Pahang River and Muar River

Its ability in rejuvenating the economic activities cannot be argued. In other Asian countries such as China, India, Bangladesh, Vietnam, Thailand and Indonesia the inland waterways have proved to boost the economic productivity. Malaysia has yet to build its own inland waterway systems. But what if this inland waterway can be developed? Is there are any potential socio-economic impact that can be brought to the local community? This is the main focus of this study, to investigate the possible socio-economic impact of future inland waterways systems connecting the Pahang and Muar rivers.

The Pahang River begins at the confluence of Jelai and Tembeling rivers on the Titiwangsa mountain range and drains into the South China Sea. The Pahang River covers a catchment area of $25,600 \mathrm{~km}^{2}$. It is the longest river in Peninsular Malaysia with a distance covering $459 \mathrm{~km}$. In the old days if traders from the either Pahang River or Muar River want to continue their journey either to Malacca or South China Sea, they could use boats up to the Pahang and Muar rivers until they could reach a place called Penarikan in Negeri Sembilan where the local help will be required to pull the boats overland. The distance is about 300 meters and because of the pulling of boats overland, the route is named Penarikan, which is the Malay word for pulling. Trading boats from Muar River could continue their journey until they reach Kuala Pahang in Pekan, or Kuala Lipis to continue into Terengganu, Kelantan or Perak. Many historical sites can be found along Pahang River. Among the sites is Lubuk Pahang Tomb which consist the tombs of Sultan Abdul Jamil, Datuk Budiman and Puteri Buluh Betong. There, a building for the British Resident was erected. It was later converted into a palace for the Sultan. Now it is the Sultan Abu Bakar Muzium.

The Muar River also offers a number of attractions. The Muar River is one of the major rivers in Malaysia. Upstream of Muar River and upstream of Pahang River are nearly connected at Penarikan (Fig. 1). There are two bridges in Muar town that cross the Muar River. The old bridge, Sultan Ismail Bridge, was built in 1967 to replace the ferry service. The Second Muar Bridge was constructed in 2005. There are a number of major attractions along this river such as Tanjung Emas Park, Tanjung Emas Jetty and Muar town's park, which is located at the estuary of Muar River. There is also a bombed bridge during World War Two located at Buloh Kasap, Segamat. Adding to this, two Sultan Ibrahim mosques, the current one situated in Muar Town while the older one located at the northern bank of the Muar River at Tanjung Agas. Its design integrated many British influences due to its construction during the British colonial period. There is another interesting place called Biawak Busuk, the place where Parameswara, the first king of Malacca transited before he went to Malacca to build his empire.

Inland waterway connecting Pahang River and Muar river- is it feasible? Development in Malaysia has rapidly changed especially after independence. 
Am. J. of Economics and Business Administration 2 (3): 240-246, 2010

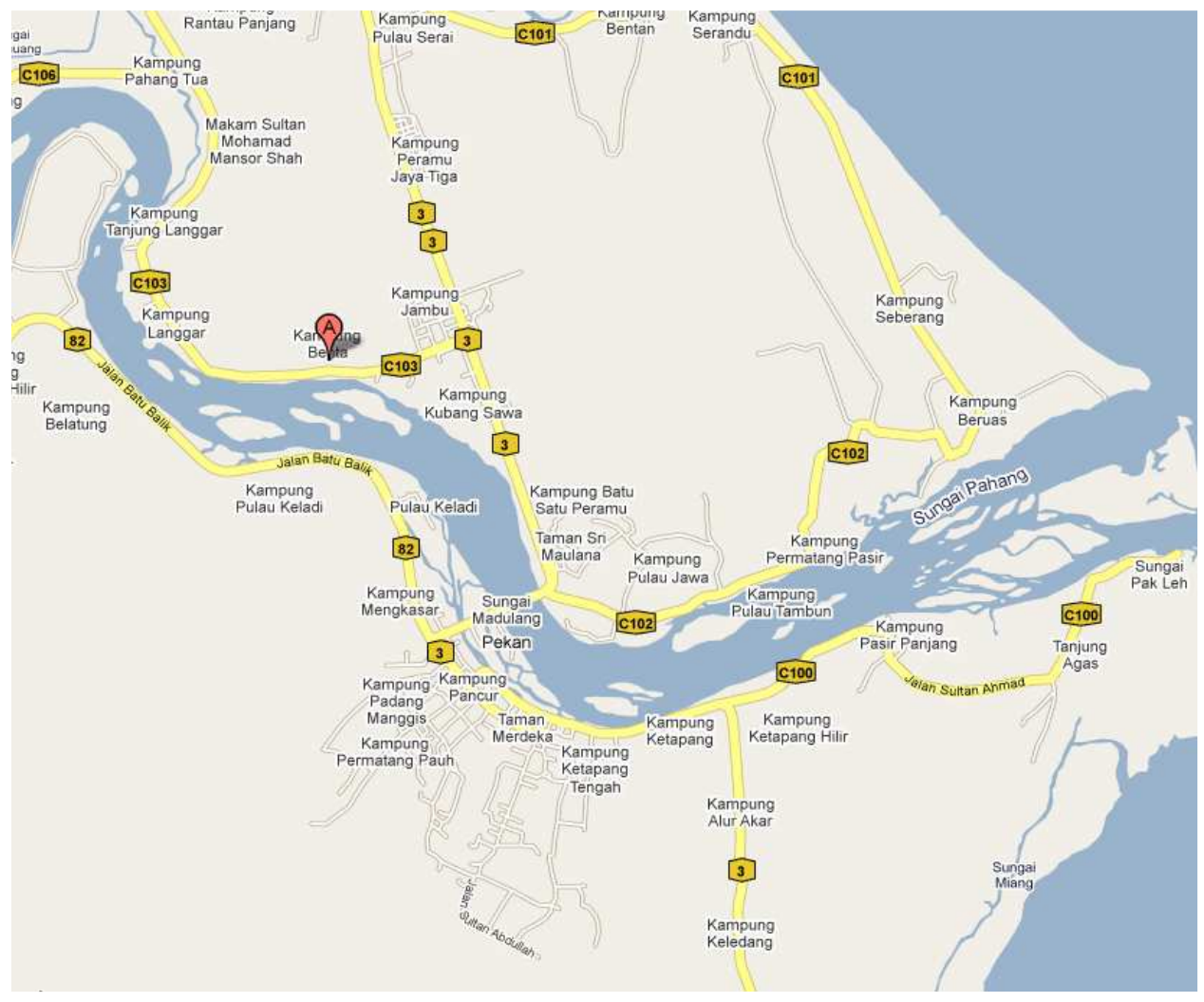

Fig. 2: The affected areas along Pahang River during dry season

Demand of modernization and globalization that drove the economic activities had changed the life of the local communities that live along the two riverine systems. Subsistence economy is not widely practiced except among the local indigenous people, for example the aborigines of Kurnia Di Raja Village, who live near the river. Palm oil and rubber estates, freshwater cages industry, recreation and sand mining are among the major money making activities that exist along these two rivers and not to forget that some of them engage in professional services either as government servants or work in private sector. Previously, these two riverine systems have been connected and it proved to profit the economic activity at that time, but, is there any possibility that this waterway can be revived and revitalized through a proper development of the full stretch joining the two rivers? The proposed project of Pekan-Muar Waterway (PMW) can be the impetus to develop the socio-economic level of the communities that live along the two rivers starting from Pekan in Pahang in the east coast to Muar in Johor on the west coast of Peninsular Malaysia

Not all the villages or places can be assessed by boat. It depends on the season. This situation will become difficult during the dry season where the water levels of the rivers become shallow especially in Pahang. The affected areas of this season are Kg. Benta, Kg. Keladi, Kg Pulau Tambun, Kg. Langgar and Kg. Tanjung Langgar (Fig. 2). As an alternative for local people, only small boats locally known as Perahu or Kolek are used to access certain places. However, this sedimentation problem is not unique to Pahang River, but also near the mouth of Muar River. Nevertheless, these two rivers still function as a significant mode of transportation to local community and authorities who live and work by the river. They are among the locals (fisherman and local traders), indigenous people-the aborigines, Cambodian migrants who have gained their permanent resident status and also the marine police. Based on this scenario, it is wise to initiate a new inland waterway system from Pekan to Muar. It is envisioned the PMW project has multi-function potentials. This proposed PMW not only offers an alternative mode of transportation for the community but could also to generate more new economic activities such as tourism and homestay, boat building, sand mining and fishing industry. There is also no doubt that it has such significant strategic importance. 
Constructing an inland waterway system will involve development in both physical and human resource development. These types of development will provide more opportunities and benefits to the surrounding communities. This spill-over effect of development has economic as well as social benefits. However, sometimes, development may result in forced displacement. It may be in the form of physical movement of the settlement (people), change in occupation, change in daily activities and so forth which demands human adaptation from the displacement. Some people may accept this as a new challenge to be faced in their lives, but to some this may disturb their routine, thus may lead to many unforeseen problems. In relation to that, as usual, development will involve costs, the bigger the development project the bigger the cost will be involved.

Besides the economic benefits, "upgrading" the waterways system from Pekan to Muar provides a better transportation from west coast to east coast and vice versa, which is shorter in distance compared to the Straits of Tebrau route. This proposed route (i.e., the project) is also strategic. The location is near to the Bandar Muazam Shah Radar centre for the south region. In fact, looking closely at the significance of the proposed project, the term strategic should not only refer to the national defense purposes but also holistically being able to complement the socioeconomic concerns. The philosophy of development without destruction in this type of development must be practiced, this include to embark on developing guidelines for sustainable development along the PMW project. This protocol will act as guidance to all users, relevant authorities and all interested parties (stakeholders) to safeguard the environmental concerns, resources utilization and other economic and social capital related to the intended project.

\section{MATERIALS AND METHODS}

In order to gain the data needed, a site survey was conducted. The PMW research team had travelled along the way (Muar to Bahau and ended in Pekan both by boat and by land along the river). Observations, structured and unstructured in-depth interview and literature analysis were used to gain the data needed. For the in-depth interviews, a total of seventeen informants were selected and there were among local leaders, government servants, fishermen and businessmen. Questions were developed and it served as a guide, but allowed respondents freedom and flexibility in their answers. Data from the FGD was transcribed verbatim and subsequently analyzed by identifying similarities and consistent themes. A constant comparative method was employed in order to uncover patterns in the data. A total of 17 transcribes were gained from the in depth interview. The data in this study is presented descriptively.

The main questions asked to the respondents were:

- What kind of development can be suggested that can bring benefits to the local community?

- What is your opinion if a waterway to be built in your place?

- Is there any development opportunity if there is waterway built in this place?

- What are the benefits to gain if there is waterway built in this place?

- In your opinion if the waterway is to be built, can it affect the flora and fauna that exist in and near to the river?

- Who are responsible to develop the river? Government or community?

- What are your roles in developing and preserving the river?

- What are the potential activities to be developed in this place?

- What are the main activities of local people at this river?

- Are there any historical places in this area?

\section{RESULTS}

\section{What local community thinks about PMW?}

Economic development: One potential that will be accrued from the huge profits offered by the PMW are the social and economic development aspects. According to Durgeloh (1966), waterways development is important in terms of encouraging economic activity. The social changes that could be brought by the inland waterways construction is hard to be measured in monetary terms, but as far as this PMW we cannot argue that it will have positive effect (McCartan and Brady, 2007). Communities who live in these three states where these two rivers flow which are Negeri Sembilan, Pahang and Johor will be exposed to a wider opportunity of uplifting their social and economic life. The introduction of PMW for sure has an outstanding ability to be an impetus for leading the economic aspect of the country. This is highly agreed upon by majority of the studied respondents. They said that boat renting is one of the potential business activities that can benefit local community. The profits of those who run this business for sure will be doubled especially during 
the school holidays. Up to this point only places such as Sungai Senduk Village and Panchor in Muar have many boat leasors. Some actions must be taken to double the number of boat renter in order to intensify the fishing activity there. The main constraint that hinders people to become a boat renter according to the local businessman is the financial problem. According to them to buy a new boat, it will cost from USD 324USD 378. Respondents agreed that the development shall have a direct impact on tourism activities which lead to the growth of transportation and related supplies and services.

Rural development through economic development opportunity: The PMW project can be one of the ingredients for the recipe of rural success. In the rural area, waterway services are pertinent in terms of ensuring the economic health of many outlying areas (Comtois et al., 1997). In the rural area, some undeveloped and neglected areas that are in direct need of instant reinforcement will have the opportunity to respond to the development offered. According to the respondents, the future PMW will create lively tourism activity which can directly attract a lot of business opportunities along the waterway. Up to this point, based on the observation of the research team, there were lack of business activity along the waterway. Through the PMW project, shops, hotels, bed and breakfast and stores selling local products for example can be established. This will provide more moneymaking activities for the rural community. Adding to this, sand mining industries, boat making industry, freshwater cages industry, boat rental activity and agriculture industry are among the industries that shall prosper. Rural development opportunities have other impacts, as also impinges upon social development and cohesion. It can be a tool to connect the rural and urban communities, in that it helps to minimize the economic disparity between the two sectors.

Development of tourism activity: The tourism activity will flourish if the PMW become a reality. This money making activity has the potential to boost the local economy and bring along additional income from tourist taxes for state and federal governments provided that policies and guidelines are established in ensuring the sustainable developments in the waterway systems (Rountree, 1999). According to the respondents, if PMW can be built, there are number of potential historical places to be developed such as:

Bukit Kepong: The historical police station of Bukit Kepong is still in a good condition. It is located at
Segamat just on the riverside of Muar River. It is well known for the patriotism of 18 policemen of Bukit Kepong Police Station who defended their police station from attack by the 180 communist insurgents. This incident happened on 23rd February 1950. This well known story has been converted to a film known as "Bukit Kepong" in 1981, mainly made to raise patriotic consciousness among the youth.

Bombed bridge at Buloh Kasap: This is a famous bombed bridge in Malaysia. Local people call this bridge as "Jambatan Patah". The British army in 1942 during the World War 2 had bombed this bridge to obstruct the advancement of Japanese army to Singapore.

Biawak Busuk: The legendary Parameswara, the first King of Malacca was narrated to visit a place called Biawak Busuk, located at Tanjung Selabu Village in Muar. It is part of the history of Malacca where Parameswara encountered lizards in large numbers. Parameswara contemplated establishing his new kingdom at either Biawak Busuk or at Kota Buruk. Finding that the Muar location was not suitable, he continued northwards to Malacca.

Penarikan: Penarikan is a name given to a place where upstream of Pahang River and upstream of Muar River are nearly connected. It was said that the legendary Malay warrior then namely Hang Tuah traveled along these two rivers, before he stopped at a place called Penarikan to pull his boat $300 \mathrm{~m}$ to the other side which is upstream of Pahang River before continuing his journey to Pahang. Besides, Penarikan played a pivotal role in the military operations between Siam and Malacca. Using this route, the Siamese had launched many attacks against Malacca. A Siamese troop was sent to make an ambush. Half of the troop stayed near Penarikan as backup and the other half attacked Malacca. However, the backup group had another mission; they have to dig a big canal measuring 30 feet by 20 feet in depth, so that they could connect the two rivers, Jempol and Serting Rivers. Jalan Penarikan has also witnessed many significant events in history. The famous Malaccan warrior Hang Tuah, while on the run with Tun Teja, used Jalan Penarikan to flee from Pahang. The last Sultan of Malacca, Sultan Mahmud Shah, after the conquest of Malacca by the Portuguese had also used Jalan Penarikan to escape to Pahang. A lot of people especially during the weekends come to Penarikan for recreational activity especially for fishing.

Sultan Ibrahim Mosque: Previously, Sultan Ibrahim Mosque was known as Muar Mosque and was built in 
1887. In 1920, a committee was formed to plan a new mosque in Muar. The main action taken by this committee was to collect donations from the public which resulted in the construction of new mosque called Sultan Ibrahim Mosque. The construction started in1925 and was completed in 1930 and was officiated by Johor Chief Minister by that time, Dato Mustafa bin Jaafar. The mosque is located at Petri Road near to the river mouth of Muar River. It offers breathtaking scenery when viewed from the mouth of Muar River. Its design incorporated many British influences due to its construction during the British colonial period.

Development of recreational activities: Inland waterway will bring huge potential to intensify recreational activities (Ken and Guy, 1991). The respondents also frequently emphasized on the famous recreational activities that their place can offer which are fishing and kayaking. Fishing is the best potential recreational activity to be developed. A lot of people according to the respondents, either local or visitors from outside come to Muar to fish for fresh lobster and Mystus spp. or locally known as "Baung", to Penarikan in Bahau for fishing Baung or (Puntius gonionotus) or locally known as Lampam and Pekan which is well known with Pangasius Sutchi or locally known as "Patin". According to them the number will be doubled during the school holidays. Based on the observation, these places attract visitors not only on weekends but also on weekdays. However, they are concerned about the social amenities and accommodation for visitor and weekend tourist. Beside, fishing as recreational activity, river expedition is another popular activity among the youngster especially among school children and teenagers. According to the respondents, many expeditions have been conducted along the two rivers. In Bahau, they have conducted the expedition from Serting River to Pahang River using canoes annually. This event is co-organized by Village Development and Security Committee (VDSC), Government of Johor State and Ministry of Tourism. There is also an expedition in 2001 where Department of Drainage and Irrigation Muar have conducted an expedition using small boats and kayaks from Pahang River and ending in Muar River covering range of more than $430 \mathrm{~km}$. Based on the experiences of these people, this activity is suitable for those who enjoy challenges and rough activity.

Enhancing quality of life: Based on the development opportunity offered, the PMW project has the huge potential in bringing sustainable economic benefits to local businesses and communities at large. According to one businessman, inland waterway form valuable corridors which run through and out of the villages and towns and they play a role in helping to define the extent and quality of urban and rural areas. As admitted by many local community leaders, the proposed PMW can drive the rural character into the heart of towns and cities and therefore carry the environmental initiatives and actions within urban areas. Inland waterway can be a mechanism for alternative transport in urban and rural areas for example, safe accessible routes for walking and cycling, towpaths for commuting or journeys to schools, opportunities for water based transport and consideration of freight potential. In addition, their diversity, beauty, history and natural environment will have positive results to the health and the subjective well-being of the local communities. According to the respondents, based on their experience, the impact of the future PMW construction such as should the river become deeper and wider, will not affect the flora and fauna along the waterway. It can be concluded that both the subjective well-being and objective well-being of the local communities in the affected area could be further developed and improved.

Reliable waterways for more sustainable mobility: An Inland waterway will offer an alternative for selection of movement for people to go to other cities and major sites of manufacturing, industry and commerce (Misra, 2007; Sudar, 2005) and the PMW also have the potential. According to the local community, in the past the river along Bukit Kepong and Muar has been used for transporting palm oil during 1930 till 1950. Besides, there was also a ferry service during $1950 \mathrm{~s}$ that provided transportation services from Bukit Kepong to Singapore. This evidence prove that this waterway has the ability to provide sustainable mobility and add some additional alternatives for people to commute or travel to other places especially during local festive seasons such as Hari Raya, Chinese New Year and Deepavali. Last but not least, Malaysia has the experience in constructing highway/motorways and as such providing an alternative mode of transport through building a highperformance waterway is not a miracle. Sustainable mobility need more than energy-efficiency and low emissions to succeed. Making better use of the future waterway network stands for smart land use and a halt to habitat fragmentation. Maintaining and developing this waterway is an opportunity to improve sustainable development. A better combination of environmental and transport initiatives should be established. Fragmented policies increasingly lead to conflicting land use, where in reality, win-win situations are 
perfectly possible benefiting sustainability and mobility. Inland waterways can contribute something to the sustainable transport in sub urban areas; it can be a main choice of transportation besides road and rail transport.

\section{DISCUSSION}

As been found by this study, the proposed PMW can have a huge significant impact in term of social development and most importantly, economic development. This directly can be become one of the tool to overcome the poverty in this country. Based on the results and literature analysis, it is believed that not only the rural people gain benefits if the proposed PMW become a reality, but also the urban people who reside in the urban area. Proposed PMW also will bring a sense of prestige to the country like what Kuala Lumpur International Airport (KLIA), Sepang F1 circuit and Proton (national car). Without doubt, the proposed PMW also will enhance the community quality of life.

\section{CONCLUSION}

Inland waterway has been proven to benefit a number of countries in the world. Asian countries such as China, India, Bangladesh, Vietnam and Thailand have proved that inland waterways can impinge upon development in their countries. Based on the study, the future inland waterway in Malaysia which could be the PMW has a huge potential that could benefit the community. Problems such as maintenance lack and finance must be solved by the related agencies. From the interviews conducted, PMW is believed to bring economic and social development, tourism development, recreational development, enhancing the quality of life and to develop sustainable mobility. It is also envisaged that the PMW could be of great strategic importance to Peninsular Malaysia.

\section{REFERENCES}

Comtois, C., B. Slack and G.K. Sletmo, 1997. Political issues in inland waterways port development: Prospects for regionalization. Transport Policy, 4: 257-265. DOI: 10.1016/S0967-070X(97)00020-6

Durgeloh, H., 1966. New inland waterway benefit port of Harmburg. Intereconomics, 1: 24-27. DOI: 10.1007/BF02922724

Ken, W. and G. Guy, 1991. Valuing open access recreation on inland waterways: On site recreation surveys and selection effects. Region. Stud. Assoc., 25: 511-524. DOI: $10.1080 / 00343409112331346687$

McCartan, M. and C. Brady, 2007. Middletown to Monaghan a social economic study of the benefits of the proposed reopening of the Ulster canal. http://www.crossborder.ie/pubs/ulster_canal.pdf

Misra, P., 2007. Dredging and integrated development of inland waterways. http://www.ieindia.org/pdf/88/88MR101.pdf

Rountree, F., 1999. Proposal for the future of Ireland's inland waterways. http://www.heritagecouncil.ie/fileadmin/user_uplo ad/Publications/Inland_Waterways/General/Propos als_Future_Irelands_Inland_Waterways.pdf

Sudar, A., 2005. Measuring non-traditional benefits and cost of inland navigation. Transport. Res. Board, 3: 47-53. DOI: 10.3141/1909-07 